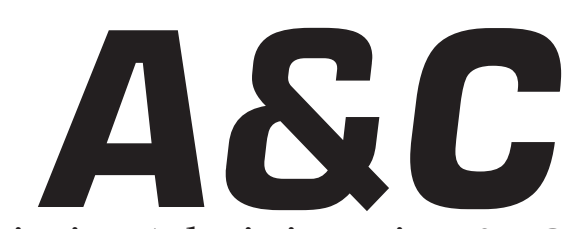

Revista de Direito Administrativo \& Constitucional

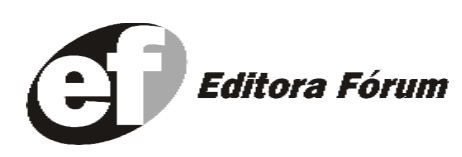

A\&C R. de Dir. Administrativo e Constitucional, Belo Horizonte, ano 4, n.17, p. 1-255, jul./set. 2004 


\section{A\&C REVISTA DE DIREITO ADMINISTRATIVO E CONSTITUCIONAL}

\section{IPDA}

Instituto Paranaense

de Direito Administrativo

Direção Geral

Romeu Felipe Bacellar Filho

Direção Editorial

Paulo Roberto Ferreira Motta

Direção Executiva

Emerson Gabardo

Conselho de Redação

Edgar Chiuratto Guimarães

Adriana da Costa Ricardo Schier

Célio Heitor Guimarães

Conselho Editorial

Adilson Abreu Dallari Luís Enrique Chase Plate

Alice Gonzáles Borges Lúcia Valle Figueiredo

Carlos Ari Sundfeld Manoel de Oliveira Franco Sobrinho (in memoriam)

Carlos Ayres Britto Marçal Justen Filho

Carlos Delpiazzo Marcelo Figueiredo

Cármen Lúcia Antunes Rocha Márcio Cammarosano

Celso Antônio Bandeira de Mello Maria Cristina Cesar de Oliveira

Clèmerson Merlin Clève Nelson Figueiredo

Clóvis Beznos Odilon Borges Junior

Enrique Silva Cimma Pascual Caiella

Eros Roberto Grau Paulo Eduardo Garrido Modesto

Fabrício Motta Paulo Henrique Blasi

Guilhermo Andrés Muñoz (in memoriam) Paulo Neves de Carvalho (in memoriam)

Jaime Rodríguez-Arana Muñoz Paulo Ricardo Schier

Jorge Luís Salomoni Pedro Paulo de Almeida Dutra

José Carlos Abraão Regina Maria Macedo Nery Ferrari

José Eduardo Martins Cardoso Rogério Gesta Leal

José Luís Said Rolando Pantoja Bauzá

José Mario Serrate Paz Sérgio Ferraz

Juan Pablo Cajarville Peruffo Valmir Pontes Filho

Juarez Freitas Yara Stropa

Julio Rodolfo Comadira Weida Zancaner

Os conceitos emitidos em trabalhos assinados são de responsabilidade de seus autores, que gozam de inteira liberdade de opinião.e-mail para remessa de artigos, pareceres e contribuições: e.gab.@uol.com.br

ou conselho@editoraforum.com.br Endereço para envio de contribuições: Editora Fórum

Revista A\&C, Av. Afonso Pena, 2770, 15\%16ª andar, Funcionários, CEP 30130-007 - Belo Horizonte - MG

A\&C Revista de Direito Administrativo e Constitucional. Ano 3, n. 11, jan./mar. 2003. Belo Horizonte: Fórum, 2003.

Trimestral

ano 1, n.1, 1999 até ano 2, n.10, 2002 publicada pela Editora Juruá em Curitiba

ISSN: $1516-3210$

1. Direito Administrativo. 2. Direito Constitucional. I. Fórum.

CDD: 342 CDU: 33.342
Editor responsável: Luis Cláudio Rodrigues Ferreira Projeto gráfico: Luis Alberto Pimenta

Diagramação: Luis Alberto Pimenta

Revisora: Olga M. A Sousa

Pesquisa jurídica: Fátima Ribeiro - OAB/MG 74868 Bibliotecária: Nilcéia Lage de Medeiros -

CRB 1545/MG - $6^{\mathrm{a}}$ região

(C) Editora Fórum Ltda 2004.

Proibida a reprodução total ou parcial desta obra,

por qualquer meio eletrônico, inclusive por processos xerográficos, sem autorização expressa do editor.

Distribuída em todo o território nacional

Assinaturas e comercialização:

Editora Fórum, Av. Afonso Pena, 2770, 15-16 andar, Funcionários, CEP 30130-007 - Belo Horizonte - MG Tel.: (31) 2121-4900 - 0800 704-3737

e-mail: editoraforum@editoraforum.com.br site: www.editoraforum.com.br 


\title{
Dworkin X Habermas, uma Discussão acerca da Legitimidade da Jurisdição Constitucional entre Substancialismo e Procedimentalismo: Novas Perspectivas
}

Mônia Clarissa Hening Leal

Professora de Teoria Constitucional e História do Direito da UNISC. Mestre pela UNISC e Doutoranda na UNISINOS

\begin{abstract}
Sumário: 1 Introdução - 2 Substancialismo x procedimentalismo: histórico e colocação do debate acerca da legitimidade da jurisdição constitucional - 3 Dworkin x Habermas e o papel da jurisdição constitucional: teoria e crítica - 4 Considerações finais - Referências
\end{abstract}

\section{Introdução}

Muitas têm sido as discussões acerca das possibilidades e dos limites da jurisdição constitucional, especialmente em meio aos pressupostos e ideais plantados pela noção de Estado Democrático de Direito, que se assenta em aspectos valorativos e materiais destacados com relação aos verificados nos modelos de Estado anteriores.

Em meio a este contexto, a discussão tem se localizado no debate substancialismo x procedimentalismo, isto é, no enfrentamento de uma percepção necessariamente mais engajada e vinculada dos tribunais constitucionais, postos como guardiães da Constituição e de seus valores, em oposição a uma noção mais identificada com a garantia e a preservação dos procedimentos democráticos, representada pela segunda corrente mencionada.

Como expoentes desta discussão podemos referir, respectivamente, o pensamento de dois autores muito significativos do pensamento jurídico atual, Ronald Dworkin e Jürgen Habermas, que protagonizam um interessante enfrentamento teórico sobre a questão.

Assim, num primeiro momento, localizaremos historicamente o foco do trabalho, analisando como o papel da jurisdição constitucional se relaciona com a teoria constitucional de cada modelo de Estado, para demonstrar o porquê da atuação destacada que se lhe confere no âmbito do Estado Democrático. Uma vez posto isto, discutiremos, então, as teorias de Dworkin e de Habermas (com relação a este, mais notadamente a posição A \& C R. de Dir. Administrativo e Constitucional, Belo Horizonte, ano 4, n. 17, p. 31-58, jul./set. 2004 
defendida em sua obra intitulada Faticidade e Validez) sobre a questão, sendo que a hipótese que se desenvolve, aqui, é a de que estes dois modelos não são excludentes entre si, mas sim imperativamente interdependentes enquanto espaços voltados para o exercício e a ampliação da democracia.

\section{Substancialismo x procedimentalismo: histórico e colocação do debate acerca da legitimidade da jurisdição constitucional}

A questão da jurisdição constitucional e de sua legitimidade tem sido objeto de inúmeros e longos debates ao longo do tempo, especialmente desde meados do século passado, quando, em meio ao segundo pós-guerra e ao florescimento de um Estado vinculado à noção de direitos humanos, deu-se um recrudescimento das funções e das atividades dos chamados Tribunais Constitucionais, que, apesar de suas variantes, ${ }^{1}$ passaram a avocar para si um papel importante no sentido de concretização e de preservação da ordem jurídica democrática estabelecida.

Tal discussão, no entanto, não está (e nem poderia estar) desvinculada da noção que a própria Constituição desempenha em cada momento histórico, de modo a ser possível afirmar que as funções e prerrogativas incorporadas por estas Cortes Constitucionais encontram na Teoria Constitucional o seu respectivo argumento, coerente com o "modelo" constitucional vigente. Assim, para os fins do presente estudo, tentaremos delinear, inicialmente, como se deu o processo de conformação desta compreensão que garante um papel de destaque ao controle de constitucionalidade, colocando o Judiciário em uma nova relação com os demais poderes constituídos do Estado, ${ }^{2}$ pois somente a partir desta perspectiva poderemos discutir os fundamentos ${ }^{3}$ teóricos e argumentativos que se somam a favor e/ou contra o seu exercício.

No que concerne a este aspecto, apesar da existência de alguns fatos que indicam a existência de uma Constituição já na Idade Antiga, ${ }^{4}$ é à Idade Moderna que se atribui a verdadeira 'invenção' da Constituição nos moldes em que a conhecemos nos dias atuais, pelo menos no que diz respeito ao pouco diferenciados: enquanto alguns - como a Alemanha - optaram por Tribunais ad hoc, outros - como é o caso do Brasil — incorporaram o Tribunal expressamente ao Poder Judiciário. Sobre os diversos modelos de jurisdição constitucional existentes, ver a obra de FIUZA, Ricardo Arnaldo Malheiros. Direito Constitucional Comparado. Belo Horizonte: Del Rey, 1997, p. 25 et seq.

2 Considerando-se, aqui, a noção clássica de tripartição dos poderes do Estado em Executivo, Legislativo e Judiciário, teorizada por Montesquieu. Cf. MONTESQUIEU. L'esprit des Lois. Paris: Gallimard, 1982.

${ }^{3}$ Conforme denota o título do trabalho, a discussão ficará limitada, aqui, à análise dos pensamentos de Ronald Dworkin e de Jürgen Habermas, que protagonizaram um dos debates mais interessantes sobre o tema.

${ }^{4}$ Conforme MATTEUCCI, Nicola. Organización del Poder y Libertad. Historia del Constitucionalismo Moderno. Trad. Francisco Javier Ansuátegui Roig y Manuel Martínez Neira. Madrid: Trotta, 1998, p. 23, com o termo 'constitucionalismo' se faz referência, geralmente, a uma reflexão sobre a experiência político-jurídica relativa 
caráter universal por ela assumido nesse período — apesar das inúmeras variantes nacionais que se podem verificar. Como diz Matteucci, ${ }^{5}$ "este é um processo histórico que apresenta alguns caracteres unitários, ainda que com modelos constitucionais distintos." Ou, como quer Häberle, ${ }^{6}$ "el actual Estado constitucional tiene muchos padres y muchas madres, en función de sus variantes nacionales pero también como tipo."

Apesar destas variantes, no entanto, a Revolução Francesa de 1789 pode ser considerada como sendo o "berço" deste novo constitucionalismo, pois, com a queda do modelo feudal, a forma concentrada de organização do poder político, justificado na vontade divina, sofre um profundo desgaste, abrindo-se espaço para a teoria do contrato social que, partindo do pressuposto de que o indivíduo está no centro da teoria política, coloca o Estado como sendo criado por um pacto firmado entre homens livres e iguais, que a ele delegam a função de assegurar as suas liberdades e os seus direitos:

El Estado no es una creación de Dios ni un orden divino, sino una comunidad (res publica) al servicio del interés común de todos los individuos. El punto de partida y la referencia obligada del ordenamiento estatal es el individuo singular, libre, igual, autodeterminado, y sus objetivos en la vida terrena; promoverlos es precisamente el por qué del Estado, el fundamento que lo legitima. ${ }^{7}$

Cria-se, assim, a idéia de que o Estado está a serviço do homem, e não o contrário, o que permite que se imponham limites às suas atividades e ao seu poder:

Así, el moderno constitucionalismo está ligado, por un lado, a los principios iusnaturalistas con su obra de racionalización del derecho vigente y, por otro, a la "revolución democrática", (...) que no fundamenta la legitimidad del poder en el derecho divino del rey, ni em la tradición, sino en el consenso racional de los ciudadanos. ${ }^{8}$

à organização do poder. E estes momentos de reflexão, segundo ele, fazem parte da história européia desde o mundo antigo.

Neste mesmo sentido, vai a afirmação de CAPPELLETTI, Mauro. O Controle Judicial de Constitucionalidade das Leis no Direito Comparado. Trad. Aroldo Plínio Gonçalves. Porto Alegre: Sergio Antonio Fabris, 1992, p. 10, quando afirma a idéia de Constituição já apresentava alguns precedentes antigos de supremacia de algumas leis tidas como 'fundamentais' sobre outras, como na Grécia, por expemplo, onde o nómos (lei em sentido estrito), quando em contraste com um pséfisma (decreto), prevalecia sobre este último.

${ }^{5}$ MATTEUCCI, Nicola. Organización del Poder y Libertad. Historia del Constitucionalismo Moderno. Trad. Francisco Javier Ansuátegui Roig y Manuel Martínez Neira. Madrid: Trotta, 1998, p. 24.

${ }^{6}$ HÄBERLE, Peter. Libertad, Igualdad, Fraternidad. 1789 como Historia, Actualidad y Futuro del Estado Constitucional. Trad. Ignacio Gutiérrez Gutiérrez. Madrid: Trotta, 1998, p. 59.

${ }^{7}$ BÖCKENFÖRDE, Ernst Wolfgang. Estudios sobre el Estado de Derecho y la Democracia. Trad. Rafael de Agapito Serrano. Madrid: Trotta, 2000, p. 19. 
Todo este processo se dá tendo como pano de fundo a instauração do Estado liberal, movido e gerido pelos interesses da burguesia, segundo os princípios iluministas do racionalismo e do antropocentrismo. Ao partir do pressuposto de que o homem é anterior ao Estado, é o seu fundamento, dá-se uma inversão na perspectiva da garantia dos direitos dos cidadãos e dos deveres do Estado, que passa a ser regido por dois princípios fundamentais: o princípio da distribuição e o princípio da organização.

O primeiro, que tem sua justificativa na idéia de que a liberdade do indivíduo é um dado anterior ao Estado, faz com que esta (a liberdade do indivíduo) seja ilimitada em princípio, ao passo que a faculdade do Estado para invadi-la seja limitada em princípio, resultando na máxima de que ao indivíduo é permitido fazer tudo aquilo que não seja proibido e, ao Estado, somente aquilo que é permitido.

Já o segundo dá origem ao princípio da separação dos poderes, forma ideal encontrada para pôr em prática o princípio da distribuição, segundo o qual o poder se divide em competências circunscritas (sistema de freios e contrapesos), o que acentua ainda mais o caráter limitado da atuação estatal.

Aliada a isto, vem a idéia de necessária mensurabilidade de todas as manifestações do poder do Estado, pela qual todas as atividades do poder devem ter um funcionamento calculável e previsível, por meio da existência de normas pré-fixadas.

Nesta perspectiva, o Estado passa a ter competências e atribuições bem delimitadas, sendo que o melhor instrumento para ordenar estes regramentos sobre competências e atribuições - e para assegurar os direitos individuais - de uma maneira neutra e racional, é a lei, que pode ser caracterizada como sendo uma regra geral (norma geral) que surge com o consentimento do povo - por meio da representatividade - num procedimento caracterizado pela discussão e pela publicidade:

Todos los principios esenciales para el Estado de Derecho están incluidos institucionalmente en este concepto de ley. (...) El asentimiento de la representación del pueblo garantiza ele principio de la libertad y la posición de sujeto del ciudadano; la generalidad de la ley impide ingerencias en el ámbito de la libertad civil y de la sociedad más allá de sus limitaciones o delimitaciones de carácter general, esto es, válidas para todos por igual; el procedimiento

\footnotetext{
${ }_{8}^{8}$ MATTEUCCl, Nicola. Organización del Poder y Libertad. Historia del Constitucionalismo Moderno. Trad. Francisco Javier Ansuátegui Roig y Manuel Martínez Neira. Madrid: Trotta, 1998, p. 25.
}

A \& C R. de Dir. Administrativo e Constitucional, Belo Horizonte, ano 4, n. 17, p. 31-58, jul./set. 2004 
determinado por la discusión y la publicidad garantiza la medida de racionalidad que el contenido de la ley puede humanamente alcanzar. ${ }^{9}$

Para poder vincular também ao Estado, porém, ela precisa ter um status diferenciado, capaz de, efetivamente, obrigar a todos os entes políticos:

O instrumento que melhor pode ordenar os regramentos sobre competências e atribuições, de uma maneira neutra e racional (sob a ótica liberal), é a lei; entretanto, para que vincule inclusive o Estado ao respeito da mesma, ela deve ter um status diferenciado, capaz de efetivamente obrigar a todos os entes políticos: o de lei constitucional. ${ }^{10}$

Está aberto, assim, o caminho para a idéia de Constituição e sua superioridade hierárquica com relação às demais normas.

É preciso considerar, no entanto, que as Constituições liberais são, ainda, do Estado, isto é, constituem um documento eminentemente jurídico cuja prerrogativa maior é a imposição de limites ao Estado e a garantia dos direitos individuais negativos. ${ }^{11}$ É no segundo pós-guerra, por sua vez, que as Constituições passam a ser concebidas como "comunitárias", ${ }^{12}$ ou seja, como sendo o reflexo dos valores compartilhados pela comunidade que as adota, dando origem à chamada Teoria Material da Constituição, que propõe

9 BÖCKENFÖRDE, Ernst Wolfgang. Estudios sobre el Estado de Derecho y la Democracia. Trad. Rafael de Agapito Serrano. Madrid: Trotta, 2000, p. 23.

10 LEAL, Rogério Gesta. Perspectivas Hermenêuticas dos Direitos Humanos e Fundamentais no Brasil. Porto Alegre: Liv. do Advogado, 2000, p. 123-124.

11 Em sede de reflexões a partir da Teoria do Estado e da Teoria da Constituição, cuja percepção histórica acerca de sua relação, caracterizada pelo Debate de Weimar, é muito bem desenvolvida por BERCOVICl, Gilberto. A Constituição Dirigente e a Crise da Teoria da Constituição. In: SOUZA NETO, Cláudio Pereira de et al. Teoria da Constituição: Estudos sobre o Lugar da Política no Direito Constitucional. Rio de Janeiro: Lumen Juris, 2003, p. 85 et seq., segundo quem pode-se indicar, como representantes desta concepção conservadora, autores como Jellinek e Laband, que afirma que a Constituição é um instrumento de governo que legitima procedimentalmente o poder, limitando-o. A política está, pois, fora da Constituição.

Um dos debates mais marcantes sobre este tema foi protagonizado por Carl Schmitt e por Hans Kelsen, que discutiram, respectivamente, sobre a necessária vinculação (ou não) da Constituição à política. A síntese desta discussão pode ser encontrada na obra de KELSEN, Hans. Jurisdição Constitucional. Trad. Alexandre Krug. São Paulo: Martins Fontes, 2003, p. 237 et seq., mais especialmente no capítulo intitulado "Quem deve ser o guardião da Constituição?"

12 Sobre a noção de Constituição comunitária e comunitarismo, ver a obra de CITTADINO, Gisele. Pluralismo, Direito e Justiça Distributiva. 2. ed. Rio de Janeiro: Lúmen Júris, 2000, p. 14 et seq., onde são traçadas as principais linhas do constitucionalismo comunitário, em oposição ao modelo liberal. No dizer da autora, os representantes do constitucionalismo comunitário se contrapõem à idéia de que a tarefa primordial da Constituição é a defesa da autonomia dos indivíduos contra um poder público inimigo: "ao sistema fechado de garantias da autonomia privada, eles opõem a idéia de Constituição aberta, que enfatiza os valores do ambiente socicultural da comunidade." Ibid., p. 16. Ver, ainda, a construção teórica sobre o tema realizada por HÄBERLE, Peter. Teoría de la Constitución como Ciencia de la Cultura. Trad. Emilio Mikunda. Madrid: Tecnos, 2000, p. 34, onde se pode ler que "la Constitución no se limita sólo a ser un conjunto de textos jurídicos o un mero compendio de reglas normativas, sino la expresión de un cierto grado de desarrollo cultural, un medio de autorrepresentación propia de todo un pueblo, espejo de su legado cultural y fundamento de sus esperanzas y deseos." 
levar em consideração o sentido, fins, princípios políticos e ideologia que conformam a Constituição. "As Constituições do Século XX, especialmente após a II Guerra Mundial, são políticas, não apenas estatais. Assumem conteúdo político, ou seja, englobam os princípios de legitimação do poder, não apenas de sua organização. O campo constitucional é ampliado para abranger toda a sociedade, não só o Estado." ${ }^{13}$

Neste contexto, o Estado abandona a sua (aparente) neutralidade e apoliticidade e assume fins políticos próprios, tomando a responsabilidade de transformar a estrutura econômica e social no sentido de uma realização material da igualdade, a fim de impedir que a desigualdade de fato destrua a igualdade jurídica. A política estatal passa a levar a cabo, então, direta ou indiretamente, uma estruturação da sociedade que se manifesta em múltiplos aspectos, estendendo o usufruto dos bens materiais e imateriais por meio do incremento dos serviços sociais, especialmente de saúde e de educação.

Na esteira dessa evolução, constitucionalizam-se catálogos mais ou menos amplos de direitos econômicos sociais e culturais - direitos estes que, contrariamente aos direitos de liberdade, não são meros poderes de agir, mas poderes de exigir. Os textos constitucionais incorporam, pois, propósitos emancipatórios, tendo como meta a correção ou transformação da ordem social e econômica vigente no sentido de consecução de uma real igualdade, de modo que também à Constituição passa a ser atribuída uma nova função, no sentido de ser um programa de ação para governados e governo.

A Constituição do Estado social não é, pois, um simples registro das relações de poder vigentes no momento constituinte, assumindo, antes, uma estrutura programática, ao compreender sempre um elemento de "utopia concreta" cuja realização é dependente da ação política.

As reações a esta noção política da Constituição, representada pelos direitos sociais - de natureza positiva, que colocam em evidência a discricionariedade do Executivo e do Legislativo - não tardaram, contudo, a aparecer, surgindo, na teoria constitucional, discussões que reclamavam um resgate e uma revalorização da normatividade ${ }^{14}$ do texto constitucional.

Neste sentido, como reflexo desta nova tendência, tem-se, de um lado, dentre outros, em meio às discussões acerca da efetivação da Constituição

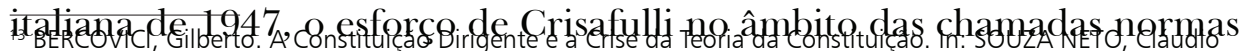
Pereira de et al. Teoria da Constituição: Estudos sobre o Lugar da Política no Direito Constitucional. Rio de Janeiro: Lumen Juris, 2003, p. 103.

${ }^{14}$ Não é nova, também, a discussão entre o caráter político e o caráter jurídico da Constituição, demarcando claramente os pressupostos da teoria constitucional de cada modelo. Como resposta e tentativa de resgate da normatividade da Constituição, tem-se o (já) clássico texto de HESSE, Konrad. A Força Normativa da Constituição. Trad. Gilmar Ferreira Mendes. Porto Alegre: Sergio Antonio Fabris, 1991. 
programáticas, ${ }^{15}$ concebidas como sendo aquelas que, apesar de conformarem direções a serem observadas pelo legislador, constituem normas jurídicas, de modo que os dispositivos sociais que contêm podem ser aplicados pelos tribunais nos casos concretos.

De outro lado, conforme referido, tem-se o desenvolvimento da idéia de Constituição Dirigente, fundada por Peter Lerche, para quem as Constituições modernas se caracterizam por possuir uma série de diretrizes constitucionais que configuram imposições permanentes para o legislador, que passa, pois, a ser compreendido como sendo realizador de uma atividade vinculada. Como refere Canotilho, a Constituição Dirigente busca racionalizar a política, incorporando uma dimensão materialmente legitimadora que estabelece um fundamento constitucional para a política, ${ }^{16} \mathrm{O}$ que implica, em última instância, na compreensão da não-disponibilidade da Constituição pelo legislador. ${ }^{17}$

Rompe-se, pois, com a noção de liberdade absoluta que era tradicionalmente conferida ao Legislativo pela teoria liberal moderna, que focalizava no aspecto representativo a legitimidade desse poder e fazia com que ele fosse, num certo sentido, superior aos demais. ${ }^{18}$

A crise desse modelo engendra, portanto, a necessidade de alterações

\footnotetext{
15 Interessante observar, neste aspecto, a ressalva feita por Bercovici, op. cit., p. 109, de que, apesar da influência e da repercussão das idéias de Crisafulli, tanto na Itália como no Brasil, sua aplicação prática foi decepcionante, de maneira que norma programática passou a ser aquela que não tem qualquer valor concreto: "toda norma incômoda passou a ser classificada como programática", bloqueando, na prática, a efetividade da Constituição e contrariando, por sua vez, a intenção original de seus divulgadores. O argumento utilizado para combater esta percepção foi o de que estas normas consistiam em meras diretivas, indicando uma direção futura (e incerta, não imediata) para o legislador, não configurando, por conseguin te, normas jurídicas, mas sim meros programas políticos.

A respeito das normas constitucionais programáticas e de sua vinculatividade, ver LAVAGNA, Carlo. Constituzione e Socialismo. Bologna: II Mulino, 1977, p. 53, quando afirma que "lo sono anche sotto il profillo impositivo. Quali norme diretti al legislatori (...) esse, non solo vietano di legiferari in senso contrario, ma 'impogno' di emanare le leggi e agli atti necessari per raggiungere i fini indicati." Também CALAMANDREI, Piero. Opere Giuridique. Napoli: Morano, 1965, v. III, p. 513-514.

${ }^{16}$ CANOTILHO, José Joaquim Gomes. Constituição Dirigente e Vinculação do Legislador: Contributo para a Compreensão das Normas Constitucionais Programáticas. Coimbra: Coimbra Ed., 1994, p. 224-225.

${ }^{17}$ É preciso ressaltar que nos referimos, aqui, à posição original do autor português, representada, dentre outras, pela obra supra citada, e não sua revisão crítica intitulada "Rever ou Romper com a Constituição Dirigente? Defesa de um Constitucionalismo Moralmente Reflexivo" (publicada nos Cadernos de Direito Constitucional e Ciência Política, n. 15, p. 7-17), onde afirma que "mesmo que as Constituições continuem a ser simbolicamente a magna carta de identidade nacional, a sua força normativa terá parcialmente de ceder perante novos fenótipos político-organizatórios, e adequar-se, no plano político e no plano normativo, aos esquemas regulativos das novas 'associações abertas de Estados nacionais abertos'." Propõe ele, por conseguinte, a substituição de um direito autoritariamente dirigente, mas ineficaz, por outras fórmulas (como os contratos) que permitam completar o projeto da modernidade nas condições da pós-modernidade. O que importa, aqui, contudo, é que o referido autor português exerceu enorme influência no meio constitucional brasileiro exatamente com base na defesa da Constituição Dirigente.
} 
no papel do Estado e do Direito, cenário propício para o surgimento do Estado de feição intervencionista, onde o pólo de tensão do poder deslocase em direção ao Executivo.

Dentro deste novo contexto, ao recear deixar a Constituição à mercê da discricionariedade do legislador, a teoria da Constituição Dirigente acaba entregando a decisão sobre as questões constitucionais ao Judiciário, especialmente porque o ponto central e nuclear desta nova ordem jurídica reside na concretização desses direitos, fazendo com que o papel dos órgãos judiciais de controle de constitucionalidade passe a ser fundamental, ou seja, a Constituição passa a

Depender fundamentalmente de mecanismos que assegurem as condições de possibilidade para a implementação de seu texto. A instrumentalização dos valores constitucionais e a aferição da conformidade ou não das leis ao texto constitucional se estabelece através do que se convencionou chamar de justiça constitucional, mediante o mecanismo da jurisdição constitucional. ${ }^{19}$

Tem-se, então, diante dos impositivos da nova versão de Estado de Direito que representa o Estado Democrático, a necessidade de concretização desses direitos, o que impõe um novo deslocamento do pólo de tensão entre os poderes, agora para o Judiciário.

Em outras palavras,

Com a tendência, cada vez maior, à "normativização" da Constituição, o papel preponderante que era da política (e dos partidos políticos) na Teoria da Constituição foi sendo tomado pelos tribunais constitucionais e pelas discussões sobre o controle de constitucionalidade. ${ }^{20}$

Segundo alguns autores, ${ }^{21}$ este processo deve-se, em especial, à (re)democratização ocorrida no segundo pós-guerra, cujo reflexo foi a incorporação e positivação, pelos textos constitucionais, dos direitos

\footnotetext{
${ }_{18}$ O Poder Legislativo desempenhava, no contexto do Estado Liberal, um papel de proeminência com relação aos demais poderes, pois era ele quem representava a sociedade civil (mais especificamente os interesses da burguesia em ascensão, que agora contava com os direitos políticos que até então lhe haviam sido sonegados), composta por indivíduos livres e juridicamente iguais; em suma, o Legislativo é o órgão de síntese racional da vontade geral rousseauniana (ao lado de outros contratualistas, como John Locke), manifestada na forma da lei (superior e vinculante para todos, especialmente para o Estado - leia-se, o Poder Executivo). Ademais, no rompimento com o regime monárquico absolutista, é compreensível que o parlamento - que representava o povo e the representava para controlar e limitar o poder do monarca absoluto - não tivesse, em princípio, nenhum tipo de limitação. O triunfo da vontade geral trouxe ínsito um deslocamento da esfera de tensão e poder do Executivo absolutista para a vontade popular-revolucionária (representada no Legislativo) que triunfou. Sem qualquer legitimidade, o Judiciário foi colocado à margem desse processo. A própria noção de Constituição não assumiu lugar cimeiro no Velho Continente, porque tratava do público, em tempos de triunfo do privado. A relevância estava no Código Civil, não no texto constitucional.

${ }^{19}$ STRECK, Lênio Luiz. Jurisdição Constitucional e Hermenêutica: uma Nova Crítica do Direito. Porto Alegre: Liv. do Advogado, 2002, p. 99.

${ }^{20}$ BERCOVICl, Gilberto. A Constituição Dirigente e a Crise da Teoria da Constituição. In: SOUZA NETO, Cláudio Pereira de et al. Teoria da Constituição: Estudos sobre o Lugar da Política no Direito Constitucional. Rio de Janeiro: Lumen Juris, 2003, p. 109.
} 
fundamentais e sociais, acompanhada da desconfiança com relação ao critério da maioria, utilizado como elemento de legitimação do nazifascismo, fazendo com que a tarefa de preservação dessa vontade fosse confiada à justiça constitucional:

A democratização social, fruto das políticas do Welfare State, o advento da democracia no segundo pós-guerra e a redemocratização de países que saíram de regimes autoritários/ditatoriais trazem à luz Constituições cujos textos positivam os direitos fundamentais e sociais. Esse conjunto de fatores redefine a relação entre os poderes do Estado, passando o Judiciário (ou os tribunais constitucionais) a fazer parte da arena política, (...) e o constitucionalismo moderno, a partir da experiência negativa de legitimação do nazi-fascismo pela vontade da maioria, confiou à justiça constitucional a guarda da vontade geral, encerrada de modo permanente nos princípios fundamentais positivados na ordem jurídica. Tais fatores provocam um redimensionamento na clássica relação entre os poderes do Estado, surgindo o Judiciário (e suas variantes de justiça constitucional, nos países que adotaram a fórmula de tribunais ad hoc) como uma alternativa para o resgate das promessas da modernidade, onde o acesso à justiça assume um papel de fundamental importância, através do deslocamento da esfera de tensão, até então calcada nos procedimentos políticos, para os procedimentos judiciais. ${ }^{22}$

Outro aspecto que se pode apontar, paralelamente a este, é, ainda, o da concentração das atividades desta natureza em um órgão centralizado, especialmente por meio do controle abstrato das normas:

After the Second World War, European countries that experienced the constitutional system's failure to protect rights, opted for centralized constitutional courts that were directly responsible for the safeguard of fundamental constitutional rights (in addition to the traditional court of competence jurisdictions. The emphasis on rights protection and the wish to constitutionalize politics resulted in abstract norms control..$^{23}$

Verifica-se, portanto, uma tendência de agigantamento do papel desempenhado pelo Judiciário dentro desta nova ordem, situação que não tardou a ser criticada, especialmente sob o viés da falta de legitimidade ou falta de representatividade de que se reveste a atividade jurisdicional — única que não tem, em meio a regimes democráticos, seus cargos providos por

\footnotetext{
${ }^{21}$ Dentre eles CITTADINO, Giselle. Judicialização da Política, Constitucionalismo Democrático e Separação de Poderes. In: VIANNA, Luiz Werneck (Org.). A Democracia e os Três Poderes no Brasil. Belo Horizonte: Ed. UFMG; Rio de Janeiro: IUPERJ/FAPERJ, 2002.

22 STRECK, Lênio Luiz. Jurisdição Constitucional e Hermenêutica: uma Nova Crítica do Direito. Porto Alegre: Liv. do Advogado, 2002, p. 128.

${ }^{23}$ ROSENFELD, Michel; ARATO, Andrew. Habermas on Law and Democracy: Critical Exchanges. London: University of California Press, 1998, p. 341.
} 
meio do voto popular - sobretudo quando se trata de conferir a este poder atribuições e responsabilidades políticas até então reservadas tão somente ao Legislativo e, numa perspectiva diferenciada, ${ }^{24}$ ao Executivo.

Em outras palavras, a questão que assume o centro do debate é: como é possível que juízes, não eleitos pelo voto popular, possam controlar e anular leis elaboradas por um poder eleito para esse fim e aplicadas por um Poder Executivo também eleito? Pode o princípio da maioria ceder espaço para a supremacia da Constituição que estabelece, em seu texto, formas de controle sobre a "liberdade de conformação do legislador"?

As críticas ${ }^{25}$ mais ferrenhas a este modelo se dão, por seu turno, sob a égide e o argumento do paternalismo representado pela jurisprudência de valores incorporada pelos tribunais constitucionais, que passam a ser, na designação de Böckenförde, os "senhores da Constituição", pois "A política foi reduzida ao poder constituinte e este, relegado a segundo plano. A jurisdição constitucional foi alçada a garantidora da correta aplicação da normatividade, a única referência de legitimidade do sistema." 26

Esta supremacia dos tribunais constitucionais sobre os demais poderes caracteriza-se, conforme esta corrente de pensamento, pelo fato de os tribunais pretenderem ser o "cume da soberania” (der Zipfel der Souveränität), sobrepondo-se aos demais poderes representativos e transformando-se, assim, em substitutos do poder constituinte soberano: "Tanto no caso do tribunal alemão, como no espanhol ou no brasileiro, o vetor interpretativo é claro: a corte constitucional respectiva deterá o monopólio de precisar o significado do poder constituinte por meio de sua atividade de controle da constitucionalidade, equiparando-se, assim, ao próprio poder constituinte." ${ }^{7}$

Seguindo nesta trilha, no dizer de Cittadino, ${ }^{28}$ já é possível falar-se em um "direito judicial" em contraposição a um "direito legal”, eis que os novos textos constitucionais, ao incorporarem princípios típicos do Estado

\footnotetext{
${ }^{24}$ Considerando-se que, no modelo do Welfare State, intervencionista, o Estado possuía uma atuação política e discricionária destacada.

25 Neste sentido, destacam-se, por exemplo, as obras de MAUS, Ingeborg. O Judiciário como Superego da Sociedade - sobre o Papel da Atividade Jurisprudencial na "Sociedade Órfã". Trad. Martonio Mont'Alverne Barreto Lima e Paulo Menezes Albuquerque. Novos Estudos, São Paulo, n. 58, nov. 2000, p. 183-202; ELY, John H. Democracy and Distrust: a Theory os Judicial Review. Cambridge: Mass, 1980; DENNINGER, Ernst. Der Gebändigte Leviathan. Baden-Baden: [s.n.], 1990; BÖCKENFÖRDE, Ernst Wolfgang. Recht, Freiheit, Staat. Frankfurt a.M.: [s.n.], 1991.

${ }^{26}$ BERCOVICl, Gilberto. A Constituição Dirigente e a Crise da Teoria da Constituição. In: SOUZA NETO, Cláudio Pereira de et al. Teoria da Constituição: Estudos sobre o Lugar da Política no Direito Constitucional. Rio de Janeiro: Lumen Juris, 2003, p. 123.

${ }_{27}$ LIMA, Martonio Mont'Alverne Barreto. Jurisdição Constitucional: um Problema da Teoria da Democracia Política. In: SOUZA NETO, Cláudio Pereira de et al. Teoria da Constituição: Estudos sobre o Lugar da Política no Direito Constitucional. Rio de Janeiro: Lumen Juris, 2003, p. 204. No mesmo sentido, Maus afirma que, neste contexto, a Justiça ascende à qualidade de administradora da moral pública, pois os "valores" são
}

A \& C R. de Dir. Administrativo e Constitucional, Belo Horizonte, ano 4, n. 17, p. 31-58, jul./set. 2004 
Democrático de Direito, asseguram o espaço necessário para interpretações construtivistas por parte da jurisdição constitucional.

A experiência, todavia, tem apontado, conforme Streck, ${ }^{29}$ para o fato de que o Estado Democrático de Direito não pode funcionar sem uma justiça constitucional. Se isto é verdade, a questão central que se coloca, então, é a de quais os fundamentos e de como deve ser dar esse controle.

Nesta seara, podem ser apontadas duas correntes em princípio antagônicas: uma substancialista, que defende a função destacada do Judiciário na garantia e na concretização dos direitos constitucionalmente estabelecidos, cujo autor a ser estudado neste trabalho é Ronald Dworkin, e outra tida como procedimentalista, aqui representada pelo pensamento de Jürgen Habermas, para quem a função daquele órgão consiste em assegurar processos democráticos.

Uma vez postas estas questões preliminares, passaremos agora a analisar o pensamento de cada um dos autores referidos no que tange à legitimidade da jurisdição constitucional.

\section{Dworkin x Habermas e o papel da jurisdição constitucional: teoria e crítica}

O pensamento de Ronald Dworkin é marcado, notadamente, pela pretensão de desenvolver uma teoria do direito e da interpretação do direito assentada na questão moral, numa clara tentativa de avanço com relação à concepção restrita e asséptica própria do positivismo jurídico. O autor propõe, nitidamente, o que se convencionou chamar de uma "leitura moral da Constituição", ${ }^{30}$ a partir da premissa de que o ordenamento jurídico não está assentado tão-somente nas leis postas, mas possui, também, valores morais que o integram.

Conforme posto pelo filósofo, o direito não pode ser meramente

usados como fator de legitimação, "imunizando as decisões contra qualquer crítica." Cf. MAUS, Ingeborg. O Judiciário como Superego da Sociedade - sobre o Papel da Atividade Jurisprudencial na "Sociedade Órfã". Trad. Martonio Mont'Alverne Barreto Lima e Paulo Menezes Albuquerque. Novos Estudos, n. 58, São Paulo, nov. 2000, p. 134.

Ressalte-se, por oportuno, que as críticas que se fazem em face da chamada jurisprudência de valores e sua adoção pelos tribunais constitucionais serão abordadas mais adiante, ao tratarmos do diálogo que se trava entre os autores objeto do presente trabalho.

${ }^{28}$ CITTADINO, Gisele. Judicialização da Política, Constitucionalismo Democrático e Separação de Poderes. In: VIANNA, Luiz Werneck (Org.). A Democracia e os Três Poderes no Brasil. Belo Horizonte: Ed. UFMG; Rio de Janeiro: IUPERJ/FAPERJ, 2002, p. 18

29 STRECK, Lênio Luiz. Jurisdição Constitucional e Hermenêutica: uma Nova Crítica do Direito. Porto Alegre: Liv. do Advogado, 2002, p. 99.

${ }^{30}$ A expressão é utilizada pelo próprio autor na introdução de um de seus livros, denominada The Moral Reading and the Majoritarian Premise. Cf. DWORKIN, Ronald. Freedom's Law. Cambridge: Mass, Harvard University Press, 1996, p. 2. 
empírico, descritivo, um mero conjunto de normas (como quer o positivismo), mas sim como um mélange de normas específicas e de princípios de justiça. Significa dizer que o direito não se limita ao direito legislado, resultado da vontade soberana do Estado, que possui o monopólio de sua produção, contexto este em que a lei — em sentido estrito - passa a desempenhar um papel de destaque enquanto manifestação racional e convencional, segundo juízos de conveniência e de utilidade que se impõem por meio da coação.

Na visão de Dworkin, não é possível separar direito e moral, ${ }^{31}$ sendo que os princípios desta decorrentes não estão sujeitos ao reconhecimento da autoridade competente, pois eles não nascem com a legislação, ${ }^{32}$ não precisam ser positivados.

Tais aspectos morais e valorativos, por sua vez, devem se fazer presentes por ocasião da interpretação, eis que são vinculantes ${ }^{33}$ para o juiz por ocasião da aplicação do direito:

El razonamiento jurídico, según Dworkin, invoca y utiliza principios que los tribunales desarrollan lentamente mediante un largo proceso de razonamiento y de creación de precedentes. Estos principios son especificamente morales. En consecuencia, el razonamiento jurídico depende del razonamiento moral, en el sentido que los principios morales juegan un papel muy importante en el razonamiento jurídico, especialmente en los casos difíciles. Y, por tanto, la tesis central del positivismo - la separación entre el derecho y la moral — es falsa. ${ }^{34}$

\footnotetext{
${ }^{31}$ Um depende do outro, embora ambos não se identifiquem; a leitura do direito é que deve ser moral. Idem. El Imperio de la Justicia. Trad. Claudia Ferrari. Barcelona: Gedisa, 1992, p. 78.

32 Percebe-se, aí, uma certa influência do jusnaturalismo, traduzida pela idéia de existência de determinados direitos naturais anteriores ao Estado e à ordem jurídica, inerentes à natureza humana enquanto tal. Note-se, no entanto, que Dworkin não pode ser identificado - como se poderia acreditar numa primeira leitura superficial — como jusnaturalista, pois não se trata de reconhecer direitos metafísicos, valores suprapositivos, antes pelo contrário: estes valores morais integram o próprio ordenamento jurídico, não se constituindo, pois, em algo externo a ele. Sobre a dificuldade de se localizar o pensamento do autor, já referia Troper: "Dworkin est précisément un auteur difficile à classer et c'est d'ailleurs ce qui fait l'intérêt de son travail. Ce qu'on peut appeler — d'un terme que, sans doute il rejetterait — as 'métatheorie' est un example frappant de cette difficulté: une métathéorie positiviste est une théorie selon laquelle la théorie du droit (ou science du droit) est distincte de son objet, le droit positif. Dworkin est, sur ce point, comme on le verra, antipositiviste. Mais, d'autre part une métathéorie positiviste est une théorie selon laquelle la théorie du droit doit décrire le droit tel qu'il est. Or, c'est bien ce que prétend faire Dworkin. II serait donc positiviste." TROPER, Michel. Les Juges Pris au Sérieux ou la Théorie du Droit Selon Dworkin. Droit et Societé: Revue Internationale de Théorie du Droit et de Sociologie Juridique, Paris, n. 2, 1986, p. 42.

Também defendendo a idéia de que Dworkin busca construir uma terceira via entre o positivismo e o jusnaturalismo, temos as referências de CALSAMIGLIA, Albert. Ensayo sobre Dworkin (Prólogo a la Edición Española). In: DWORKIN, Ronald. Los Derechos en Serio. Trad. Marta Gustavino. Madrid: Ariel, 1997, p. 12.

${ }^{33}$ Mais uma vez, reforça-se a compreensão, referida na nota anterior, de que estes aspectos morais e valorativos integram a própria ordem jurídica, pois, caso fossem externos a ela, não poderiam ser tidos como impositivos, mas tão-somente como desejáveis (noção de bom, e não do que é devido).
} 
Esses princípios, que no dizer de Troper ${ }^{35}$ são tanto descritivos como prescritivos (descritivos porque preexistem à discussão judiciária e prescritivos porque não é possível afirmar que determinado princípio é o mais adequado), todavia, não oferecem uma solução unívoca, de modo que se torna necessário recorrer a uma argumentação. Esta argumentação, por sua vez, não é positivada, mas valorativa, operada no caso concreto. ${ }^{36}$

Dworkin desenvolve, assim, uma série de pressupostos interpretativos ${ }^{37}$ em sua obra, ${ }^{38}$ sempre no sentido de justificar que a interpretação no campo jurídico é uma atividade criativa - comparando-a, por vezes, com a interpretação literária — onde a resposta correta (right answer $)^{39}$ é aquela que atribui o melhor sentido à prática social em questão. ${ }^{40}$ Muitas são as críticas tecidas no que tange à possibilidade ou impossibilidade de se obter uma resposta correta nos hard cases, mas o fato é que o autor traz a discussão para a perspectiva da diferença que se verifica entre as práticas interpretativas - que possuem um caráter de ordem interna — e a ciência em seu sentido experimental, que trabalha com elementos

\footnotetext{
${ }^{34}$ CALSAMIGLIA, Albert. Ensayo sobre Dworkin (Prólogo a la Edición Española). In: DWORKIN, Ronald. Los Derechos en Serio. Trad. Marta Gustavino. Madrid: Ariel, 1997, p. 11.

35 TROPER, Michel. Les Juges Pris au Sérieux ou la Théorie du Droit Selon Dworkin. Droit et Societé: Revue Internationale de Théorie du Droit et de Sociologie Juridique, Paris, n. 2, 1986, p. 47.

${ }^{36}$ Dworkin exemplifica a questão utilizando o problema, relacionado ao conteúdo da Primeira Emenda da Constituição americana, da pornografia e da liberdade de expressão x censura, dizendo o seguinte: "So when some novel or controversial constitutional issue arises - about whether, for instance, the First Amendment permits laws against pornography - people who form an opinion must decide how an abstract moral principle is best understood. They must decide whether the true ground of the moral principle that condemns censorship, in the form in wich this principle has been incorporated into American law, extends to the case of pornography." DWORKIN, Ronald. Freedom's Law. Cambridge: Mass, Harvard University Press, 1996, p. 2.

${ }^{37} \mathrm{O}$ autor identifica três etapas distintas na interpretação: uma primeira, tida como pré-interpretativa, que consiste na identificação das regras sociais (embora também aqui se exija uma atividade interpretativa, pois as regras sociais não possuem etiquetas de identificação); a segunda consiste na justificação da prática (debate sobre por que esta prática social é válida); e, por fim, a etapa pós-interpretativa, em que o intérprete ajusta o conteúdo da prática social para que ela possa servir à melhor justificação, identificada na etapa anterior.

Estas etapas, contudo, ao contrário do que se poderia imaginar, não são sucessivas, como bem adverte Bonorino ao referir que "Dworkin reconoce que la tarea interpretativa resulta mucho menos deliberada y estructurada que lo que puede dar a entender esta distinción tripartida." BONORINO, Pablo Raúl. El Imperio de la Interpretación: los Fundamentos Hermenéuticos de la Teoría de Dworkin. Cuadernos Bartolomé de las Casas, Madrid, n. 29, 2003, p. 25.

${ }^{38}$ Ver, para tanto, especialmente DWORKIN, Ronald. El Imperio de la Justicia. Trad. Claudia Ferrari. Barcelona: Gedisa, 1992, p. 44 et seq.

${ }^{39}$ No dizer de Guastini, "Beaucoup d'essais de Dworkin aboutissent à une même conclusion univoque: pour chaque question de droit il existe toujours une 'réponse juste' (right answer), une solution correcte du point de vue du droit en vigueur. Cela équivaut à dire justement que le droit est complet ou au moins 'complétable' par le juge sans employer aucune 'discrétion'. (...) Par l'usage de principes du droit, alors même les cas qui échappent aux prévisons du législateur auront néanmoins une solution juridique aproppriée." GUASTINI, Ricardo. Théorie et Ontologie du Droit chez Dworkin. Droit et Societé: Revue Internationale de Théorie du Droit et de Sociologie Juridique, Paris, n. 2, 1986, p. 17.

40 Dworkin refere que este é o elemento comum de todas as formas de interpretação (que ele classifica em científica, artística e social): o fato de que cada uma tenta fazer de seu objeto o melhor que ele pode ser. Cf. DWORKIN, Ronald. El Imperio de la Justicia. Trad. Claudia Ferrari. Barcelona: Gedisa, 1992, p. 49.
} 
externos, como demonstra a acurada análise acerca de sua obra feita por Rodríguez:

El hecho de que no sea posible "demostrar" la corrección de una interpretación en ámbitos como el jurídico o el literario, no implica que carezca de sentido hablar de la existencia de una respuesta correcta. La demostración es propia de áreas del conocimiento como la ciencia, en que existen hard facts externos a la práctica científica, que sirven como punto de evaluación de la corrección de una afirmación. (...) Por ser una práctica interpretativa, entre tanto, el derecho puede entenderse sólo desde el interior del proceso de argumentación en el que dos o más participantes reivindican la corrección de su interpretación de las normas. ${ }^{41}$

De outra banda, é possível depreender, pelo exposto, que a moralidade de que trata o autor não é uma moralidade sociológica, mas sim uma moralidade racional, em que o princípio essencial é o da igualdade. ${ }^{42}$ Em outras palavras, o julgamento deve ser substantivo.

Trata-se, portanto, do reconhecimento, por parte de Dworkin, de que as decisões devem ser justificadas desde um ponto de vista moral, o que traz à tona, em parte, a discussão acerca da subjetividade de tais decisões e, conseqüentemente, da (i)legitimidade da atuação dos juízes neste sentido, eis que isto violaria as competências típicas do Legislativo. Uma vez que estas questões são transpostas também para o âmbito da Constituição, tais argumentos passam a ser ainda mais questionados.

Para Dworkin, todavia, essa leitura moral não possui nada de revolucionário, a não ser o fato de admitir e explicitar esta vinculação:

So, to repeat, the moral reading is not revolutionary in practice. Lawyers and judges, in their day-to-day work, instinctively treat the Constitution as expressing abstract moral requirements that can only be applied to concrete cases through fresh moral judgments. As I shall argue later in this introduction, they have no real option but to do so. But it would indeed be revolutionary for a judge openly to recognize the moral reading, or to admit it. (...) There is therefore a striking mismatch between the role the moral reading actually plays in American constitutional life and its reputation. ${ }^{43}$

Ademais, o autor busca resolver o impasse ao estabelecer o

\footnotetext{
${ }^{41}$ RODRÍGUEZ, César. La Decisión Judicial: el Debate Hart - Dworkin. Santafé de Bogotá: Siglo del Hombre, 1997, p. 85.

${ }^{42}$ A preocupação central com o princípio da igualdade pode ser facilmente percebida em seus textos, especialmente quando traz à colação discussões atuais e concretas como discriminação positiva, etc., características de seu trabalho. Ver, para tanto, especialmente DWORKIN, Ronald. Virtud Soberana: la Teoría y la Práctica de la Igualdad. Trad. María Julia Bertomeu y Fernando Aguiar. Barcelona: Piados, 2003, p. 25 et seq.
} 
pressuposto de que o juiz está vinculado a determinados princípios preexistentes, ${ }^{44}$ ou seja, o argumento de que o autor se vale é o de que, ao estar vinculado a determinados princípios - ainda que abertos e genéricos - o magistrado desenvolve uma atividade vinculada - o que não significa, contudo, que ela não prescinda de interpretação ${ }^{45}$-, e não uma atividade puramente discricionária:

Ainsi, em faveur de l'idée que le juge n’a pas de pouvoir discrécionnaire et qu'il est toujours lié par des príncipes préexistants, Dworkin emploie l'argument de la démocratie: si le juge disposait d'um pouvoir discrétionnaire, cela signifierait qu'il dispose d'un pouvoir de création du droit; dans um système démocratique, le droit ne peut être créé que par des représentants élus du peuple souverain; or, le système américain est un système démocratique. Donc, dans le système américain, les juges, qui ne sont pas des représentants élus, n’ont pas le pouvoir de créer du droit et sont liés par des principes. ${ }^{46}$

\section{Além disso, como refere Leader,}

C'est une caractéristique des juges, affirme-t-il, de trouver le droit et non pas de le faire. Il leur appartient de donner effet aux droits préexistants des parties qui se présentent devant eux. En faisant cela, ils doivent, ce qu'ils font de caractéristique, éviter les decisions fondées sur des considerations de politique et suivre au contraire la direction indiquée par les principes. Les politiques déterminent des buts, décrivent une vision du bien commun de la societé et sont normalement l'affaire du législatif. ${ }^{47}$

De outro lado, é preciso considerar que o filósofo americano deixa bem claro que esta tarefa interpretativa vinculada não significa, todavia, que o magistrado deva buscar, por ocasião da aplicação do princípio, a interpretação que os legisladores — responsáveis pela inserção do referido princípio no ordenamento - lhe teriam dado. ${ }^{48}$ Antes pelo contrário: os juízes não lêem suas próprias conviç̧ões na Constituição, porque o capítulo

${ }^{43}$ Id. Freedom's Law. Cambridge: Mass, Harvard University Press, 1996, p. 3.

44 "La thèse de Dworkin apparaît alors comme un renversement de perspective, puisqu'il soutient que le juge n'a jamais de pouvoir discrétionnaire, qu'il doit toujours appliquer un droit préexistant, mais que ce droit n'est pas toujours un droit posé et que, à côté des regles, il y a des principes et des droits naturels." TROPER, Michel. Dossier Ronald Dworkin. Droit et Societé: Revue Internationale de Théorie du Droit et de Sociologie Juridique, Paris, n. 1, 1985, p. 28

45 "Selon Dworkin, rien dans le système juridique ne se présente naturellement, directement comme interpreté. C'est un de ses arguments fondamentaux contre les positivists. (...) L'interprétation doit être donnée par le juge, toujours à la lumière de la théorie politique la plus appropriée." LEADER, Sheldon. Le Juge, la Politique et la Neutralité: a Propos des Travaux de Ronald Dworkin. Droit et Societé: Revue Internationale de Théorie du Droit et de Sociologie Juridique, Paris, n. 2, 1986, p. 29

${ }^{46}$ TROPER, Michel. Les Juges Pris au Sérieux ou la Théorie du Droit Selon Dworkin. Droit et Societé: Revue Internationale de Théorie du Droit et de Sociologie Juridique, Paris, n. 2, 1986, p. 51.

47 LEADER, Sheldon. Le Juge, la Politique et la Neutralité: a Propos des Travaux de Ronald Dworkin. Droit et Societé: Revue Internationale de Théorie du Droit et de Sociologie Juridique, Paris, n. 2, 1986, p. 26. 
que eles escrevem deve estar conectado ${ }^{49}$ com a história escrita até então; mas não se pode desconsiderar, por outro lado, que são eles os seus autores:

Judges may not read their own convictions into the Constitution. They may not read the abstract moral clauses as expressing any particular moral judgement, no matter how much that judgement appeals to them, unless they find it consistent in principle with the structural design of the Constitution as a whole, and also with the dominant lines of past constitutional interpretation by other judges. They must regard themselves as partners with other officials, past and future, who together elaborate a coherent constitutional morality, and they must take care to see that what they contribute fits with the rest. (I have elsewhere said that judges are like authors jointly creating a chain novel in wich each writes a chapter that makes sense as part of the story as a whole. ${ }^{50}$

Tem-se, pois, por parte de Dworkin, uma espécie de percepção ao mesmo tempo criativa e vinculada da interpretação e da aplicação do direito pelos tribunais que lhe é bastante peculiar.

É nesta perspectiva, por sua vez, ao referir que as críticas à leitura moral da Constituição pelos juízes é hiperbólica, que o autor deixa claro que essa prática não é, de modo algum, contrária ao princípio republicano:

When we understand democracy better, we see that the moral reading of a political constitution is not antidemocratic but, on the contrary, is practically indispensable to democracy. I do not mean that there is no democracy unless judges have the power to set aside what a majority thinks is right and just. (...) Democracy does not insist on judges having the last word, but it does not insist that they must not have it. ${ }^{51}$

\footnotetext{
48 "We are governed by what our lawmakers said — by the principles they laid down — not by any information we might have about they themselves would have interpreted those principles or applied them in concrete cases." DWORKIN, Ronald. Freedom's Law. Cambridge: Mass, Harvard University Press, 1996, p. 10. O mesmo pensamento é desenvolvido mais profundamente em DWORKIN, Ronald. Uma Questão de Princí pio. Trad. Luís Carlos Borges. São Paulo: Martins Fontes, 2000, p. 12 et seq.

A referência, aqui, diz respeito a uma corrente oposta ao pensamento de Dworkin e que protagonizou um intenso debate nos Estados Unidos com relação à interpretação da Constituição: os chamados originalistas. Para estes, a Constituição deve ser interpretada de acordo com as circunstâncias determinantes por ocasião de sua criação; o significado original de seu texto, ou seja, as intenções originais dos constituintes devem ser preservadas, de modo que os juízes não estão autorizados a alterar o seu significado. Como diz Pulido, a corrente originalista assegura que "la principal técnica interpretativa para determinar qué derechos están garantizados por l a Constitución, cons is te en indagar aquello que los constituyentes manifestarían, si tuviesen $\quad$ q $u \quad$ e aplicar actualmente el texto que en su momento crearon." Cf. PULIDO, Carlos Bernal. El Principio de Proporcionalidad y los Derechos Fundamentales. Madrid: Centro de Estudios Constitucionales, 2003, p. 215.

${ }^{49} \mathrm{O}$ autor chama atenção para o fato de que alguém poderia alegar, neste contexto, que os juízes, ao desempenhar tal atividade, poderiam abusar do poder que lhes é assegurado. A resposta, contudo, é simples: se os juízes podem, os presidentes, os religiosos, qualquer um pode abusar do poder que lhe é atribuído. A questão central que se pressupõe, por sua vez, é a boa-fé, pois "the moral reading is a strategy for lawyers and judges acting in good faith, wich is all any interpretive strategy can be." Ver, para tanto, DWORKIN, Ronald. Freedom's Law. Cambridge: Mass, Harvard University Press, 1996, p. 11.
} 
Aliás, a nosso ver, é neste aspecto que reside uma das maiores contribuições do autor, pois acreditamos que uma discussão acerca do papel e dos limites da jurisdição constitucional não pode vir desvinculada de uma teoria da democracia, ${ }^{52}$ isto é, de uma construção daquilo que se entende como sendo seus pressupostos e atributos essenciais.

Segundo Dworkin, nem sempre a premissa da maioria deve governar, uma vez que os participantes destas deliberações podem vir a agir movidos por interesses privados e egoístas, negando as premissas maiores da igualdade e da integridade. ${ }^{53}$ Valem, neste sentido, as palavras de Pulido, quando afirma que

Según este autor, no parece plausible considerar que las deliberaciones parlamentarias puedan ser la fuente de la interpretación constitucionalmente correcta de los derechos fundamentales, pues los participantes en dichas deliberaciones actúan movidos por intereses privados. Por lo tanto, estima que los derechos fundamentales no pueden ser catalogados como el objeto sino como el límite de los procedimientos democráticos. (...) Ninguna decisión mayoritaria puede invadir la esfera de las libertades proclamadas por la Constitución y que si alguna incurre en esta transgreción, debe ser invalidada por el Juez Constitucional. ${ }^{54}$

É nestas circunstâncias, por sua vez, que a função do controle de constitucionalidade se torna essencial, ao assegurar a garantia dos direitos fundamentais contra maiorias eventuais: $: 55$

La doctrina de Dworkin sobre el control de constitucionalidad reconstruye las relaciones entre el Juez Constitucional y el Legislador como una contraposición. El Juez Constitucional aparece considerado como un valedor de los derechos fundamentales y de las minorías, que se enfrenta a la voluntad general, expre-

\footnotetext{
51 Ibid., p. 7.

${ }^{2}$ Dworkin deixa isto claro em inúmeros de seus textos, especialmente em DWORKIN, Ronald. Uma Questão de Princípio. Trad. Luís Carlos Borges. São Paulo: Martins Fontes, 2000, p. 4 et seq., onde, no capítulo primeiro, desenvolve a idéia de que as concepções acerca da jurisdição constitucional e do papel desempe nhado pelos direitos fundamentais estão diretamente vinculadas à concepção que se tem acerca do Estado e da democracia. No mesmo sentido, ainda, ver DWORKIN, Ronald. Freedom's Law. Cambridge: Mass, Harvard University Press, 1996, p. 15, em que ele discute a questão da premissa majoritária, e DWORKIN, Ronald. Virtud Soberana: la Teoría y la Práctica de la Igualdad. Trad. Fernando Aguiar y María Julia Bertomeu. Barcelona: Piados, 2003, p. 203 et seq., quando são discutidas questões como a igualdade política.

53 Dworkin distingue duas formas de agir coletivo: a estatística — que nada mais é do que um somatório das ações e das vontades individuais - e a comunitária (comunal), onde a vontade é posta enquanto grupo dimensão coletiva. Cf. DWORKIN, Ronald. Freedom's Law. Cambridge: Mass, Harvard University Press, 1996, p. 19-20.

54 PULIDO, Carlos Bernal. El Principio de Proporcionalidad y los Derechos Fundamentales. Madrid: Centro de Estudios Constitucionales, 2003, p. 217-218.

Sobre uma concepção material de democracia, ver, também, a obra de BILBENY, Norbert. Democracia para la Diversidad. Barcelona: Ariel, 1999, p. 12, especialmente no prólogo, intitulado "La mayoría no siempre tiene razón". Já com relação à defesa do modelo majoritário, ver o interessante estudo realizado por BAYÓN, Juan Carlos. Derechos, Democracia y Constitución. In: CARBONELL, Miguel. Neoconstitucionalismo(s). Madrid: Trotta, 2003, p. 212 et seq.

55 É exatamente nisto que reside a sua vinculação com os substancialistas, conforme referido acima. Sobre a distinção entre substancialistas e procedimentalistas, ver a obra de STRECK, Lênio Luiz. Jurisdição Consti tucional e Hermenêutica: uma Nova Crítica do Direito. Porto Alegre: Liv. do Advogado, 2002, p. 127
} 
sada en las determinaciones del Parlamento. Las decisiones de uno y otro poder del Estado se rigen por lógicas distintas. Mientras el contenido de las leyes es el producto de la aplicación de la regla de la mayoría, el resultado de las sentencias del Juez Constitucional está determinado por la lógica de los derechos fundamentales. Sin embargo, de acuerdo con Dworkin, este antagonismo no debe llevar a pensar que el control constitucional de las leyes supone un deterioro del principio democrático. ${ }^{56}$

Dworkin, todavia, acrescenta um outro argumento a favor da legitimidade dos tribunais ao asseverar que, em meio a um regime democrático em que não há uma igualdade genuína de poder político e no qual muitos cidadãos são inteiramente destituídos de privilégios, aqueles que não possuem representatividade ganham mais do que perdem, enquanto que outros ganham em poder político com essa transferência:

Essas imperfeições no caráter igualitário da democracia são bem conhecidas e, talvez, parcialmente irremediáveis. Devemos levá-las em conta ao julgar quanto os cidadãos individualmente perdem de poder político sempre que uma questão sobre direitos individuais é tirada do legislativo e entregue aos tribunais. Alguns perdem mais do que outros apenas porque têm mais a perder. Devemos também lembrar que alguns indivíduos ganham em poder político com essa transferência de atribuição institucional. ${ }^{57}$

Os tribunais desempenham, portanto, segundo esta perspectiva, um papel importante na construção de uma maior distribuição do poder político, ou, melhor dizendo, no exercício da participação polítca.

No dizer de Dworkin, mesmo que se possa alegar que o acesso ao Poder Judiciário é caro e, portanto, restrito (o que favoreceria os ricos), normalmente o acesso ao Legislativo é ainda mais restrito, de modo que transferir algumas decisões do Legislativo poderia ser mais valioso para os pobres: ${ }^{58}$

Membros de minorias organizadas, teoricamente, têm mais a ganhar com a transferência, pois o viés majoritário do Legislativo funciona mais severamente contra eles, e é por isso que existe mais probabilidade de que seus direitos sejam ignorados nesse fórum. Se os tribunais tomam a proteção de direitos individuais como et seq. sua responsabilidade especial, então as minorias ganharão em poder político. ${ }^{59}$

Sobre a evolução das decisões da Suprema Corte americana neste sentido, especialmente a partir da 14 a Emenda, ver o texto de MELO, Manuel Palácios Cunha. A Suprema Corte dos EUA e a Judicialização da Política: Notas sobre um Itinerário Difícil. In: VIANNA, Luiz Werneck (Org.). A Democracia e os Três Poderes no Brasil. Belo Horizonte: Ed. UFMG; Rio de Janeiro: IUPERJ/FAPERJ, 2002, p. 73.

${ }_{56}$ PULIDO, Carlos Bernal. El Principio de Proporcionalidad y los Derechos Fundamentales. Madrid: Centro de Estudios Constitucionales, 2003, p. 218.

${ }^{57}$ DWORKIN, Ronald. Uma Questão de Princípio. Trad. Luís Carlos Borges. São Paulo: Martins Fontes, 2000, p. 31.

${ }^{58}$ Especialmente se se considerarem institutos como a justiça gratuita, dentre outros.

A \& C R. de Dir. Administrativo e Constitucional, Belo Horizonte, ano 4, n. 17, p. 31-58, jul./set. 2004 
Assim, conforme o autor, "Não há nenhuma razão para pensar, abstratamente, que a transferência de decisões sobre direitos, das legislaturas para os tribunais, retardará o ideal democrático da igualdade de poder político. Pode muito bem promover este ideal." ${ }^{60}$

O processo e a jurisdição constituir-se-iam, por conseguinte, em um novo espaço de cidadania. Para tanto, porém, o processo precisaria ser visto sob uma nova perspectiva, isto é, enquanto uma nova instância reservada ao indivíduo no exercício de suas prerrogativas de cidadania.

Habermas ${ }^{61}$ constitui-se, neste aspecto, no pensador que melhor realiza este diálogo com Dworkin, especialmente ao tomar como referência a atuação eminentemente substancialista do Tribunal Constitucional alemão, que compreende a Constituição como sendo uma "ordem concreta de valores", reconhecendo, assim, a existência de um direito além do direito posto, que tem sua fonte na ordem constitucional considerada em sua totalidade. ${ }^{62}$

Segundo o autor, esta postura desconhece a distinção entre princípios e valores, onde os primeiros são tidos como deontológicos e os segundos, como teleológicos. Em outras palavras, as normas (entendidos aqui os princípios como tal) obrigam seus destinatários sem exceção e por igual, enquanto que os valores não são mais do que preferências intersubjetivamente compartidas: "Las normas se presentan con una pretensión binaria de validez y son, o bien válidas, o bien no válidas. (...) En cambio, los valores

\footnotetext{
59 Ibid., p. 32.

60 lbid., loc. cit.

${ }^{61}$ Especialmente em sua obra Faticidade e Validez, na qual concentraremos nosso trabalho.

62 Em 1951, o Tribunal Constitucional alemão decidiu que "Das Bundesverfassungsgericht erkennt die Existenz überpositiven, auch den Verfassungsgesetzgeber bindenen Rechtes an und ist zuständig, das gesetzte Recht daran zu messen." BUNDESVERFASSUNGSGERICHT. Entscheidungen des Bundesverfassungsgericht. Tübingen: J.C.B. Mohr, 1952. s. 18.

Já em 14 de fevereiro de 1973 adotou uma resolução, transcrita por Habermas, que diz que "El derecho no se identifica con la totalidad de las leyes escritas. Frente a lo positivamente estabelecido por el poder del Estado puede haber a veces un plus en lo que toca a derecho, que tiene su fuente en el orden constitucional considerado como una totalidad de sentido y que puede actuar como correctivo frente a la ley escrita; encontrar ese plus y realizarlo en sus decisiones es tarea de la jurisprudencia constitucional." BverGE 34, 269, s. 304. A transcrição encontra-se em HABERMAS, Jürgen. Facticidad y Validez: sobre el Derecho y el Estado Democrático de Derecho en Términos de Teoría del Discurso. Trad. Manuel Jiménez Redondo. Madrid: Trotta, 1998, p. 317.

Também o Tribunal Constitucional espanhol adota esta leitura valorativa com relação à Constituição, ao decidir, em 21 de março de 1981, que "la Constitución es una norma cualitativamente distinta de las demás, por cuanto incorpora el sistema de valores esenciales que ha de constituir el orden de convivencia política e informar todo el ordenamiento jurídico." Sobre esta e outras decisões de cunho valorativo do Tribunal Constitucional espanhol, ver LAVILLA, Landelino. Constitucionalidad y Legalidad. Jurisdicción Constitucional y Poder Legislativo. In: PINA, António López. División de Poderes e Interpretación: hacia una Teoría de la Praxis Constitucional. Madrid: Tecnos, 1997, p. 56.
} 
fijan relaciones de preferencia que dicen que determinados bienes son más atractivos que otros; de ahí que nuestro asentimiento a los enunciados valorativos consienta grados." ${ }^{3}$

Desta forma, essa noção valorativa desconsidera o sentido jurídico dos direitos fundamentais, fazendo com que eles passem a desempenhar um novo papel. Isto porque, conforme Habermas, a distinção entre normas e valores só não é supérflua para quem acredita em valores universais.

É exatamente este, a nosso ver, o ponto central da crítica - ou melhor, do diálogo - que Habermas propõe com relação ao pensamento de Dworkin: não há valores universais e imutáveis, dados, especialmente em se tratando de sociedades que não possuem tradições e valores históricos compartilhados.

Por isso Habermas propõe substituir a moralidade e os valores preexistentes por um processo comunicativo, de construção de identidades; em outras palavras, o pensador alemão pretende substituir a noção de uma nação de cultura por uma nação de cidadãos. ${ }^{64}$

Tal aspecto aparece com propriedade no texto de Cittadino, quando refere que

Segundo Habermas, a concepção de comunidade de princípios não poderia ter sido formulada se Dworkin não vislumbrasse uma dimensão de continuidade na história, que aqui se traduz na obrigação do juiz de ajustar a sua interpretação às práticas e à história americana e ao resto da Constituição. (...) O que Habermas assinala, portanto, é que o modelo hermenêutico proposto por Dworkin, de uma interpretação racionalmente construída a partir de princípios substantivos, somente é possível graças à sua confiança nas tradições e práticas constitucionais americanas. No entanto, nos contextos históricos em que não se pode apelar para um republicanismo cívico ou para uma comunidade de princípios que compartilha tradições e valores históricos e culturais, a visão substantiva da democracia constitucional deve ser substituída por uma visão procedimental da democracia constitucional. ${ }^{65}$

Tem-se, portanto, que Habermas configura, contra Dworkin, um modelo de democracia constitucional que não se fundamenta nem em valores compartilhados, nem em conteúdos substantivos, mas em procedimentos que asseguram a formação democrática da opinião, que exige uma identidade política pós-convencional, e não mais histórica e valorativamente ${ }^{63}$ HABERMAS, Jürgen. Facticidad y Validez: sobre el Derecho y el Estado Democrático de Derecho en Términos de Teoría del Discurso. Trad. Manuel Jiménez Redondo. Madrid: Trotta, 1998, p. 328.

64 Ibid., p. 359.

${ }^{65}$ CITTADINO, Gisele. Judicialização da Política, Constitucionalismo Democrático e Separação de Poderes. In: VIANNA, Luiz Werneck (Org.). A Democracia e os Três Poderes no Brasil. Belo Horizonte: Ed. UFMG; Rio de Janeiro: IUPERJ/FAPERJ, 2002, p. 20-21.

A \& C R. de Dir. Administrativo e Constitucional, Belo Horizonte, ano 4, n. 17, p. 31-58, jul./set. 2004 
determinada, assentada em certos ideais compartilhados. Tais referenciais precisam, nesta perspectiva, ser construídos. ${ }^{66}$

É por isto que o processo comunicativo é visto como um projeto aberto, pois, na perspectiva de Habermas, quanto mais a moral se torna autônoma, mais ela pende para o reforço do âmbito privado. A moralidade deve, portanto, vir e estar associada ao procedimento, e não ser algo que existe de per si, aprioristicamente:

In principle, it is an open-ended project. (...) The more morality is internalized and becomes autonomous, the more it withdraws to the private realm. That is why social problems that ask for an unequivocal and binding regulation cannot be solved by leaving them to practical moral-reasoning. Instead, legal norms (set by the legislature) and procedures (of application) have to offer an imperative compensation for the uncertainties of pure morally guided human action. ${ }^{67}$

Para esta construção pressupõe-se, por sua vez, a participação de cidadãos (daí falar-se em uma nação de cidadãos), capazes de produzir um agir comunicativo, entendido como um "Discurso orientado para o entendimento, que assegura aos falantes participantes no acto de comunicação um mundo da vida intersubjetivamente partilhado, garantindo assim simultaneamente um horizonte no seio do qual todos se possam referir a um só mundo objectivo." 68

Rompe-se, pois, com a compreensão, posta pela jurisprudência de valores, de que a Constituição traduz a autocompreensão ético-normativa de uma comunidade, e de que as Cortes Constitucionais, porque vinculadas a esta eticidade substantiva, têm a função primordial de aproximar as normas constitucionais da realidade histórica. Neste contexto, segundo Habermas, a Constituição, em meio ao pluralismo social e cultural, ${ }^{69}$ não pode ser entendida como uma ordem jurídica global e concreta, que impõe a priori para a sociedade um determinado tipo de vida. Antes pelo contrário,

La Constitución fija los procedimientos políticos conforme a los que los ciudadanos, ejercitando sus derechos de autodeterminación, pueden perseguir cooperativa-

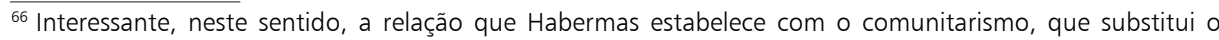
contrato por promessas recíprocas que se renovam, isto é, o fundamento anterior é substituído por uma prática pós-convencional. Ver, para tanto, HABERMAS, Jürgen. Facticidad y Validez: sobre el Derecho y el Estado Democrático de Derecho en Términos de Teoría del Discurso. Trad. Manuel Jiménez Redondo. Madrid: Trotta, 1998, p. 355 (nota 71).

${ }^{67}$ BAL, Peter. Discourse Ethics and Human Rights in Criminal Procedure. In: DEFLEM, Mathieu. Habermas, Modernity and Law. London: Sage, 1996, p. 86.

${ }^{68}$ HABERMAS, Jürgen. Racionalidade e Comunicação. Trad. Paulo Rodrigues. Lisboa: Edições 70, 1996, p. 192.
} 
mente y con perspectivas de éxito el proyecto de establecer formas justas de vida (lo cual quiere decir: cada vez más justas). Sólo las condiciones procedimentales de la génesis democrática de las leyes aseguran la legitimidad del derecho establecido. ${ }^{70}$

A função primordial do Tribunal Constitucional seria, então, a de assegurar a autonomia pública e privada ${ }^{71}$ dos cidadãos (concepção procedimentalista), em contraposição à concepção paternalista ${ }^{72}$ que lhe é atribuída pela jurisprudência de valores.

Tal compreensão funda-se, por sua vez, numa perspectiva republicana, ${ }^{73}$ onde a cidadania, concebida como uma liberdade positiva, pressupõe a participação entre livres e iguais, istoé, onde a observância recíproca de direitos e deveres se funda em relações simétricas de reconhecimento. Neste contexto, o papel estatal não é visto como um dado que precisa ser controlado, mas como resultado da ação comunicativa (a função do Estado não é só garantir os direitos subjetivos, mas a participação).

Assim, a justificação dos direitos não reside no fato de a sociedade ser composta por portadores de direitos (pensamento liberal), mas no fato de que estes são uma decorrência do processo democrático:

La sociedad política no es primariamente una sociedad de portadores de derechos, sino una sociedad de ciudadanos, una "sociación" cuyo primer principio es el establecimiento de un ámbito público en el que los miembros de la sociedad, reunidos, argumenten y razonen acerca del modo correcto de 69 "Pero esta eticidad sustancial de un consenso de fondo, que se supone aproblemático, se compadece mal con las condiciones de pluralismo cultural y social que caracteriza a las sociedades modernas." HABERMAS, Jürgen. Facticidad y Validez: sobre el Derecho y el Estado Democrático de Derecho en Términos de Teoría del Discurso. Trad. Manuel Jiménez Redondo. Madrid: Trotta, 1998, p. 354.

${ }^{70}$ Ibid., p. 336.

${ }^{71}$ Este é considerado um dos aspectos centrais da obra de Habermas, isto é, a relação circular que se estabelece entre a autonomia pública e a privada, de maneira que uma reforça a outra: "Persons are autonomous, however, only in the same measure that they can be understood at the same time as the autors of the law to wich they are subject as addressees. (...) What Habermas has made as a central if not the central argument of the book is the circular relationship between private and public autonomy. (...) The first principle of that argument is that the autonomy of citizens and the legitimacy of law 'refer' to each other. In a 'postmetaphysical' world 'the only legitimate law is one that emerges from the discursive opinion - and will-formation of equally entitled citizens of a state. The point is that private and public autonomy reinforce each other." RASMUSSEN, David M. How is Valid Law Possible? A Review of Between Facts and Norms by Jürgen Habermas. In: DEFLEM, Mathieu. Habermas, Modernity and Law. London: Sage, 1996, p. 41.

72 Dentre os autores que mais ferrenhamente criticam a noção paternalista da jurisdição constitucional está ELY, John H. Democracy and Distrust: a Theory of Judicial Review. Cambridge: Mass, 1980, p. 100. O ceticismo do autor se dirige contra esta compreensão porque, segundo ele, ela se nutre de uma desconfiança generalizada contra a figura de um legislador dependente das lutas pelo poder e de opiniões majoritárias

73 Habermas contrapõe a concepção republicana à concepção liberal, assentada nos direitos negativos dos cidadãos frente ao Estado: "El republicanismo liga la legitimidad de las leyes al procedimiento democrático de su génesis (...), mientras que para los liberales algunos derechos se fundan siempre en un derecho superior basado en una razón transpolítica o en la revelación." HABERMAS, Jürgen. Facticidad y Validez: sobre el Derecho y el Estado Democrático de Derecho en Términos de Teoría del Discurso. Trad. Manuel Jiménez Redondo. Madrid: Trotta, 1998, p. 345.

A \& C R. de Dir. Administrativo e Constitucional, Belo Horizonte, ano 4, n. 17, p. 31-58, jul./set. 2004 
organizar su existencia social, modo que habrán de establecer ellos conjuntamente y que habrán de entender como su bien común... De ahí que el Estado se justifique por su finalidad de establecer y ordenar esa esfera pública dentro de la cual las personas puedan alcanzar libertad en el sentido de un autogobierno practicado mediante el ejercicio de la razón en el diálogo público. ${ }^{74}$

A política é vista, portanto, como uma questão de valor, e não só como uma questão de preferência; como um processo de razão, e não só como uma manifestação de vontade, de maneira que a deliberação é tida como uma atitude de cooperação social, que consiste "Em la apertura a dejarse persuadir por razones relativas a derechos de los otros al igual que a los derechos de uno mismo. El medio de la deliberación es un intercambio de puntos de vista, efectuado de buena fé." 75

A ação comunicativa de que se trata, aqui, pressupõe uma abertura ao outro, remetendo àquilo que Habermas denomina de ação comunicativa em sentido forte, na qual

Os participantes referem-se a orientações de valor intersubjetivamente partilhadas que - indo para além de suas preferências pessoais — vinculam as suas vontades. (...) No caso da acção comunicativa forte, é não só a liberdade de escolha arbitrária que é pressuposta, mas também a autonomia, no sentido de união de vontades com base em discernimentos normativos. ${ }^{76}$

Todavia, como adeverte Alexy, "La idea del discurso sólo puede realizarse en un Estado constitucional democrático, en el que los derechos fundamentales y democracia, a pesar de todas las tensiones, entren en una inseparable asociación." 77

Entendemos, no entanto, que a questão da legitimidade e da legitimação da jurisdição constitucional não passa somente por estes aspectos, nem acreditamos que a ação comunicativa — ainda que ela se realize em termos ideais — não é suficiente para a consecução da idéia democrática no âmbito judicial.

A nosso ver, não há como desvincular a democracia da perspectiva material, de modo que se trata, muito mais, nesta discussão, de se poder perceber os discursos de Dworkin e de Habermas como interdependentes, 75 Ibid., p. 347.

${ }^{76}$ Id. Racionalidade e Comunicação. Trad. Paulo Rodrigues. Lisboa: Edições 70, 1996, p. 205. A ação comunicativa num sentido forte se opõe, segundo o autor, à ação comunicativa num sentido fraco, que se refere a expressões de vontade unilaterais. Em outras palavras, a última entende-se como voltada para o entendimento (a expressão utilizada no original é Verständigung), ao passo que a primeira é tida como orientada para a concordância (Einverständniss). Ibid., p. 214.

77 ALEXY, Robert. Teoría del Discurso y Derechos Humanos. Trad. Luís Villar Borda. Bogotá: Universidad Externado de Colómbia, 1995, p. 131. 
como dois aspectos imperativos e que se complementam no exercício da jurisdição constitucional (e também no processo em sentido amplo, de uma maneira geral), do que como lógicas excludentes.

Em Dworkin, o juiz não deve buscar sozinho a melhor justificação da prática (deve contar com a atuação dos envolvidos no processo, argumentativamente). Assim, não há paternalismo, mas mais um espaço de atuação dos indivíduos (extensão da cidadania); mas o juiz deve decidir tendo por pressuposto e observando este respeito recíproco e coletivo assentado na igualdade, que tanto Dworkin como Habermas ${ }^{78}$ pressupõem.

Defendemos, pois, a idéia de que a jurisdição deve ser tomada como um espaço de ampliação da cidadania, onde o processo possa ser inclusivo enquanto local de exercício de participação política (lato sensu), de democracia direta, ${ }^{79} \mathrm{em}$ que os integrantes desta "nação de cidadãos" pensada por Habermas ajam, sim, comunicativamente, mas sempre orientados pelos valores postos pela própria Constituição e que, necessariamente, também devem envolver e vincular os magistrados por ocasião do exercício de sua função decisória. O exercício argumentativo deve ser focalizado exatamente na melhor justificação para os valores e princípios nela contidos.

\section{Considerações finais}

Historicamente, tem-se atribuído, à jurisdição constitucional, um espaço destacado de atuação política, especialmente em face dos fundamentos valorativos e materiais que identificam o Estado Democrático de Direito.

Neste contexto, Ronald Dworkin, a partir de sua teoria interpretativa do direito centrada na figura do juiz, impõe a este, no exercício de sua atividade, a tarefa de preservação e de implementação dos valores morais que incorporam e integram o ordenamento jurídico. À jurisdição se atribui, por conseguinte, uma função eminentemente material e valorativa, assentada na busca pela melhor justificativa para a prática social em questão (right answer).

Já para Habermas, por sua vez, não existem valores predefinidos

\footnotetext{
78 "La formación democrática de la voluntad no extrae su fuerza legitimadora de la convergencia previa de convicciones éticas en las que se ha crecido, sino de presuposiciones comunicativas y procedimientos que en el proceso de deliberación permiten imponerse a los mejores argumentos." HABERMAS, Jürgen. Facticidad y Validez: sobre el Derecho y el Estado Democrático de Derecho en Términos de Teoría del Discurso. Trad. Manuel Jiménez Redondo. Madrid: Trotta, 1998, p. 353.

${ }^{79}$ A compreensão posta aqui é aquela desenvolvida por Bobbio no sentido de que o futuro da democracia passa pela ampliação da democracia direta — em associação com a democracia representativa — e pela ampliação dos espaços de participação política por parte dos cidadãos. A nosso ver, a jurisdição constitu cional precisa ser um destes novos espaços. Ver BOBBIO, Norberto. O Futuro da Democracia: uma Defesa das Regras do Jogo. Trad. Marco Aurélio Nogueira. 4. ed. Rio de Janeiro: Paz e Terra, 1989, p. 56.
}

A \& C R. de Dir. Administrativo e Constitucional, Belo Horizonte, ano 4, n. 17, p. 31-58, jul./set. 2004 
e absolutos que possam ser "encontrados" ou "descobertos" pelo magistrado; antes pelo contrário, estes conteúdos precisam ser construídos, argumentativa e discursivamente (ação comunicativa) no processo, daí a idéia de que a função primordial dos tribunais constitucionais é a garantia e a implementação de(os) procedimentos democráticos. Rompe-se, pois, com uma percepção paternalista e interventiva com relação ao Judiciário.

A idéia que defendemos, no entanto, é a de que, nesta disputa, não há vencedores, pois ambos os aspectos defendidos são fundamentais e imprescindíveis, devendo ser percebidos, antes, como vinculados e interdependentes entre si: a jurisdição constitucional precisa resgatar mais amplamente as possibilidades de atuação democrática e emancipadora das partes, bem como o enfrentamento de posicionamentos divergentes (discurso, comunicação), mas sem perder de vista os aspectos valorativos que marcam o modelo do Estado Democrático de Direito, registrados nos princípios que integram a Constituição.

Assim, o que se pretende é que o processo passe a se constituir em um novo locus de exercício da cidadania, orientado pela atuação ativa e efetiva dos indivíduos, porém sem perder de foco a sua vinculação com os valores que norteiam a nossa sociedade. Não há democracia sem conteúdo, assim como também não há conteúdo que possa prescindir do procedimento. Tem-se, por conseguinte, que os valores são vinculativos, mas que a sua real dimensão de conteúdo não se encontra pairando, de forma absoluta, no ar. Faz-se necessário que ela seja construída - daí a importância do procedimento entre cidadãos —, porém sempre tendo como referência aqueles fins postos, de maneira que ambos - conteúdo e procedimento — não podem, sob este prisma, vir dissociados.

Esta convergência e interação é que pautam, a nosso ver, o desafio da jurisdição constitucional no sentido de sua legitimação e legitimidade. Referências

ALEXY, Robert. Teoría del Discurso y Derechos Humanos. Traducción de Luís Villar Borda. Bogotá: Universidad Externado de Colómbia, 1995.

BAL, Peter. Discourse Ethics and Human Rights in Criminal Procedure. In: DEFLEM, Mathieu. Habermas, Modernity and Law. London: Sage, 1996. p. 71-100.

BAYÓN, Juan Carlos. Derechos, Democracia y Constitución. In: CARBONELL, Miguel. Neoconstitucionalismo(s). Madrid: Trotta, 2003. p. 211-238.

BERCOVICI, Gilberto. A Constituição Dirigente e a Crise da Teoria da Constituição. In: A \& C R. de Dir. Administrativo e Constitucional, Belo Horizonte, ano 4, n. 17, p. 31-58, jul./set. 2004 
SOUZA NETO, Cláudio Pereira de et al. Teoria da Constituição: Estudos sobre o Lugar da Política no Direito Constitucional. Rio de Janeiro: Lumen Juris, 2003. 261 p.

BILBENY, Norbert. Democracia para la Diversidad. Barcelona: Ariel, 1999.

BOBBIO, Norberto. O Futuro da Democracia: uma Defesa das Regras do Jogo. Tradução de Marco Aurélio Nogueira. 4. ed. Rio de Janeiro: Paz e Terra, 1989.171 p.

BÖCKENFÖRDE, Ernst Wolfgang. Estudios sobre el Estado de Derecho y la Democracia. Traducción de Rafael de Agapito Serrano. Madrid: Trotta, 2000.

BONORINO, Pablo Raúl. El Imperio de la Interpretación: los Fundamentos Hermenéuticos de la Teoría de Dworkin. Cuadernos Bartolomé de las Casas, Madrid, n. 29, 2003.

BUNDESVERFASSUNGSGERICHT. Entscheidungen des Bundesverfassungsgericht. Tübingen: J.C.B. Mohr, 1952.

CALAMANDREI, Piero. Opere Giuridique. Napoli: Morano, 1965. v. III.

CALSAMiglia, Albert. Ensayo sobre Dworkin (Prólogo a la Edición Española). In: DWORKIN, Ronald. Los Derechos en Serio. Traducción de Marta Gustavino. Madrid: Ariel, 1997.

CANOTILHO, José Joaquim Gomes. Constituição Dirigente e Vinculação do Legislador: Contributo para a Compreensão das Normas Constitucionais Programáticas. Coimbra: Coimbra Ed., 1994.

CANOTILHO, José Joaquim Gomes. Rever ou Romper com a Constituição Dirigente? Defesa de um constitucionalismo moralmente reflexivo. Cadernos de Direito Constitucional e Ciência Política, n. 15, p. 7-17.

CAPPELLETTI, Mauro. O Controle Judicial de Constitucionalidade das Leis no Direito Comparado. Tradução de Aroldo Plínio Gonçalves. Porto Alegre: Sergio Antonio Fabris, 1992.

CARBONELL, Miguel. Neoconstitucionalismo(s). Madrid: Trotta, 2003.

CITTADINO, Gisele. Pluralismo, Direito e Justiça Distributiva. 2. ed. Rio de Janeiro: Lúmen Júris, 2000.

CITTADINO, Gisele. Judicialização da Política, Constitucionalismo Democrático e Separação de Poderes. In: VIANNA, Luiz Werneck (Org.). A Democracia e os Três Poderes no Brasil. Belo Horizonte: Ed. UFMG; Rio de Janeiro: IUPERJ/FAPERJ, 2002.

DWORKIN, Ronald. El Imperio de la Justicia. Traducción de Claudia Ferrari. Barcelona: Gedisa, 1992.

DWORKIN, Ronald. Freedom's law. Cambridge: Mass, Harvard University Press, 1996.

DWORKIN, Ronald. Los Derechos en Serio. Traducción de Marta Gustavino. Madrid: Ariel, 1997.

DWORKIN, Ronald. Uma Questão de Princípio. Tradução de Luís Carlos Borges. São Paulo: Martins Fontes, 2000.

DWORKIN, Ronald. Virtud Soberana: la Teoría y la Práctica de la Igualdad. Traducción de María Julia Bertomeu y Fernando Aguiar. Barcelona: Piados, 2003.

ELY, John H.. Democracy and Distrust: a Theory of Judicial Review. Cambridge: Mass, 1980.

FIUZA, Ricardo Arnaldo Malheiros. Direito Constitucional Comparado. Belo Horizonte: Del

A \& C R. de Dir. Administrativo e Constitucional, Belo Horizonte, ano 4, n. 17, p. 31-58, jul./set. 2004 
Rey, 1997.

GUASTINI, Riccardo. Théorie et Ontologie du Droit chez Dworkin. Droit et Societé: Revue Internationale de Théorie du Droit et de Sociologie Juridique, Paris, n. 2, 1986. p. 15-22.

HÄBERLE, Peter. Libertad, Igualdad, Fraternidad. 1789 como Historia, Actualidad y Futuro del Estado Constitucional. Traducción de Ignacio Gutiérrez Gutiérrez. Madrid: Trotta, 1998.

HÄBERLE, Peter. Teoría de la Constitución como Ciencia de la Cultura. Traducción de Emilio Mikunda. Madrid: Tecnos, 2000.

HABERMAS, Jürgen. Racionalidade e Comunicação. Tradução de Paulo Rodrigues. Lisboa: Edições 70, 1996.

HABERMAS, Jürgen. Facticidad y Validez: sobre el Derecho y el Estado Democrático de Derecho en Términos de Teoría del Discurso. Traducción de Manuel Jiménez Redondo. Madrid: Trotta, 1998.

HESSE, Konrad. A Força Normativa da Constituição. Tradução de Gilmar Ferreira Mendes. Porto Alegre: Sergio Antonio Fabris, 1991.

KELSEN, Hans. Jurisdição Constitucional. Tradução de Alexandre Krug. São Paulo: Martins Fontes, 2003.

LAVAGNA, Carlo. Constituzione e Socialismo. Bologna: Il Mulino, 1977.

LAVILLA, Landelino. Constitucionalidad y Legalidad. Jurisdicción Constitucional y Poder Legislativo. In: PINA, António López. División de Poderes e Interpretación: Hacia una Teoría de la Praxis Constitucional. Madrid: Tecnos, 1997, p. 53-67.

LEADER, Sheldon. Le Juge, la Politique et la Neutralité: a Propos des Travaux de Ronald Dworkin. Droit et Societé: Revue Internationale de Théorie du Droit et de Sociologie Juridique, Paris, n. 2, 1986, p. 23-40.

LEAL, Rogério Gesta. Perspectivas Hermenêuticas dos Direitos Humanos e Fundamentais no Brasil. Porto Alegre: Liv. do Advogado, 2000.

LIMA, Martonio Mont'Alverne Barreto. Jurisdição Constitucional: um Problema da Teoria da Democracia Política. In: SOUZA NETO, Cláudio Pereira de et al. Teoria da Constituição: Estudos sobre o Lugar da Política no Direito Constitucional. Rio de Janeiro: Lumen Juris, 2003 .

MATTEUCCI, Nicola. Organización del Poder y Libertad. Historia del Constitucionalismo Moderno. Traducción de Francisco Javier Ansuátegui Roig y Manuel Martínez Neira. Madrid: Trotta, 1998.

MELO, Manuel Palácios Cunha. A Suprema Corte dos EUA e a Judicialização da Política: Notas sobre um Itinerário Difícil. In: VIANNA, Luiz Werneck (Org.). A Democracia e os Três Poderes no Brasil. Belo Horizonte: Ed. UFMG; Rio de Janeiro: IUPERJ/FAPERJ, 2002.

PULIDO, Carlos Bernal. El Principio de Proporcionalidad y los Derechos Fundamentales. Madrid: Centro de Estudios Constitucionales, 2003.

STRECK, Lênio Luiz. Jurisdição Constitucional e Hermenêutica: uma Nova Crítica do Direito. Porto Alegre: Liv. do Advogado, 2002. 710 p.

RASMUSSEN, David M.. How is Valid Law Possible? A Review of Between facts and Norms by Jürgen Habermas. In: DEFLEM, Mathieu. Habermas, Modernity and Law. London: Sage, 1996, p. 21-44.

A \& C R. de Dir. Administrativo e Constitucional, Belo Horizonte, ano 4, n. 17, p. 31-58, jul./set. 2004 
RODRÍGUEZ, César. La Decisión Judicial: el Debate Hart - Dworkin. Santafé de Bogotá: Siglo del Hombre, 1997.

ROSENFELD, Michel; ARATO, Andrew. Habermas on Law and Democracy: Critical Exchanges. London: University of California Press, 1998.

TROPER, Michel. Dossier Ronald Dworkin. Droit et Societé: Revue Internationale de Théorie du Droit et de Sociologie Juridique, Paris, n. 1, 1985, p. 27-30.

TROPER, Michel. Les Juges pris au Sérieux ou la Théorie du Droit selon Dworkin. Droit et Societé: Revue Internationale de Théorie du Droit et de Sociologie Juridique, Paris, n. 2, 1986, p. 41-56. 